\title{
IMPLEMENTASI CROWDSOURCING DALAM DUNIA PERPUSTAKAAN
}

\author{
Dewi Puspitasari \\ Perpustakaan Universitas Airlangga \\ E-mail: dewi.unair@gmail.com
}

\begin{abstract}
ABSTRAK
Dunia sangat cepat bergerak. Ada suatu fenomena gotong royong oleh anggota masyarakat untuk satu tujuan tertentu. Setiap orang berhak dan diperbolehkan memberikan informasi yang diperlukan. Fenomena tersebut disebut sebagai crowdsourcing. Crowdsourcing merupakan konsep yang melibatkan masyarakat secara luas dan tidak terbatas dengan latar belakang etnis, warga negara, pendidikan, agama, jenis kelamin ataupun pekerjaan. Tulisan ini akan membahas bagaimana konsep crowdsourcing dapat diimplementasikan ke dalam perpustakaan. Sebagaimana jamak diketahui perpustakaan merupakan lembaga nirlaba yang menyediakan jasa layanan informasi kepada pemustaka. Pemustaka atau bahkan masyarakat secara luas dapat ikut serta memberikan ide, gagasan atau pendapat dalam rangka mempromosikan perpustakaan. Aktivitas tersebut antara lain adalah: (1) Resensi oleh para pemustaka; (2) Komen/rekomendasi pemustaka mengenai suatu koleksi yang telah dibaca; (3) Magang di perpustakaan; (4) Library volunteer; (5) Pemustaka ikut serta membuat subject guide
\end{abstract}

Keywords: crowdsourcing, outsourcing, library

\section{PENDAHULUAN}

Dunia begitu cepat bergerak. Perubahan dalam dunia merupakan keniscayaan. Perkembangan ilmu pengetahuan dan teknologi membawa dunia dalam akselerasi perubahan yang signifikan. Media sosial dan internet menjadikan orang dapat terkoneksi secara langsung dan dapat saling berbagi banyak hal. Sosial media telah dikenal oleh mayoritas masyarakat. Melalui sosial media, tidak saja menghimpun komunikasi antara satu orang dengan orang yang lain. Media sosial juga dapat menyatukan satu kelompok masyarakat untuk berkomunikasi secara aktif untuk satu tujuan tertentu.

Di Surabaya, ada gerakan saling membantu di kalangan masyarakat yang digawangi oleh suatu radio terkenal. Melalui media sosial yang dikelola oleh radio tersebut, masyarakat dapat berpartisipasi dalam suatu informasi. Setiap orang memiliki kesempatan yang sama untuk menambahkan suatu informasi. Pada akhirnya keberadaan media sosial tersebut sangat membantu. Mulai dari melaporkan kondisi lalu lintas, melaporkan suatu kejadian misal kebakaran, pencurian, kehilangan, prestasi dan lain sebagainya. Setiap orang secara sukarela melaporkan atau menambahkan informasi melalui media sosial tersebut.
Fenomena tersebut dinamakan gotong royong oleh anggota masyarakat untuk satu tujuan tertentu. Setiap orang berhak dan diperbolehkan memberikan informasi yang diperlukan. Tentu saja informasi yang diberikan harus sesuai dengan kebutuhan dan tidak melanggar norma, SARA, aturan tidak tertulis di tengah-tengah masyarakat.

Fenomena tersebut disebut sebagai crowdsourcing. Crowdsourcing merupakan konsep yang melibatkan masyarakat secara luas dan tidak terbatas dengan latar belakang etnis, warga negara, pendidikan, agama, jenis kelamin ataupun pekerjaan. Konsep crowdsourcing serupa namun tidak sama dengan konsep outsourcing. Outsourcing mengalihkan pekerjaan kepada institusi atau perusahaan lain, sedangkan crowdsourcing mengalihkan pekerjaan tersebut kepada masyarakat luas. Selain itu, nuansa yang kental dalam crowdsourcing adalah prinsip gotong royong. Masyarakat secara luas ikut berperan dalam crowdsourcing karena ada rasa memiliki dan kecintaan terhadap sesuatu. Bukan karena terpaksa atau dipaksa.

Lalu pertanyaan selanjutnya, apakah konsep crowdsourcing dapat diaplikasikan di dalam dunia perpustakaan dan kepustakawanan. Perpustakaan merupakan lembaga nirlaba yang memungkinkan 
masyarakat luas atau khususnya bagi pemustakanya untuk berpartisipasi untuk suatu kegiatan tertentu. Bagaimana implikasi konsep crowdsourcing di dalam perpustakaan. Apa keuntungan perpustakaan menerapkan konsep crowdsourcing dalam layanan yang disajikan. Tulisan ini akan membahas bagaimana konsep crowdsourcing dapat diimplementasikan ke dalam perpustakaan. Sebagaimana jamak diketahui perpustakaan merupakan lembaga nirlaba yang menyediakan jasa layanan informasi kepada pemustaka.

\section{Mengenal Crowdsourcing}

Crowdsourcing secara harafiah dapat diartikan secara kata per kata. Crowdsourcing terdiri atas dua komponen, yaitu: crowd, yang berarti kerumunan orang, dan sourcing, yang berarti sumber daya. Bila digabungkan, maka terjemahan bebasnya dapat diartikan sebagai sesuatu sistem atau konsep sumber daya berbasis kerumunan (Andriansyah, et al., 2009).

Wikipedia menerjemahkan crowdsourcing sebagai urun daya, adalah proses untuk memperoleh layanan, ide, maupun konten tertentu dengan cara meminta bantuan dari orang lain secara massal, secara khusus melalui komunitas daring. Proses ini sering kali digunakan dalam penggalangan dana maupun aksi sosial, dan dilakukan secara dalam jaringan dan luar jaringan. Cara kerjanya dengan menggabungkan usaha dari beberapa sukarelawan atau pekerja paruh waktu, yang mana masing-masing dari mereka memiliki inisiatif tersendiri untuk mencapai hasil yang maksimal. Contoh penerapannya adalah Wikipedia, yang membutuhkan banyak sukarelawan dalam membentuk sebuah proyek ensiklopedia internet untuk bisa diakses dan dapat dibaca siapa saja.

Dalam lingkup bisnis, crowdsourcing merupakan salah satu bentuk pemasaran. Menurut Alam \& Campbell (2012), crowdsourcing merupakan "the act of taking a job traditionally performed by a designated agent (usually an employee) and outsourcing it to an undefined, generally large group of people in the form of an open call. Crowdsourcing adalah sebuah istilah yang sering digunakan untuk menggambarkan suatu proses dalam mendapatkan pekerjaan ataupun pendanaan dari sekelompok orang dalam jumlah banyak melalui fasilitas online. Konsep yang digunakan untuk menjalankan teknik ini adalah dengan tersedianya orang-orang dalam kelompok besar untuk berpartisipasi menghasilkan konten.
Secara lebih spesifik, crowdsourcing didefinisikan sebagai suatu aktivitas atau tindakan yang dilakukan oleh suatu perusahaan atau institusi yang mengambil salah satu fungsi pekerjaan atau tugas yang seharusnya dilakukan oleh karyawannya menjadi disebarluaskan secara terbuka dan bebas untuk orang banyak atau kerumunan yang terkoneksi dengan jaringan komputer, dalam hal ini adalah internet (Howe, 2009).

Konsep umum crowdsourcing adalah adanya pelibatan yang tidak terbatas dan tanpa memandang latar belakang pendidikan, kewarganegaraan, agama, amatir atau profesional, bagi setiap orang yang ingin memberikan kontribusinya atau solusinya atas suatu permasalahan yang dilemparkan oleh individu, perusahaan atau institusi. Kontributor dapat dibayar (mendapatkan upah atau reward), mendapatkan royalti, namun tidak tertutup kemungkinan bahwa kontributor memberikan kontribusi secara cuma-cuma atau tidak dibayar. Konsep khusus crowdsourcing adalah suatu perusahaan atau institusi ingin mendapatkan solusi atas permasalahan yang mereduksi birokrasi dengan biaya yang rendah dibandingkan dengan membayar tenaga kerja secara konvensional, sedemikian hingga permasalahan dapat ditangani secara cepat, tepat dan hemat biaya, yang pada akhirnya baik secara langsung maupun tidak langsung akan meningkatkan daya saing perusahaan atau institusi tersebut.

Secara sederhana, konsep khusus crowdsourcing diinterpretasikan sebagai suatu perusahaan yang memperkerjakan karyawan baru dari kerumunan tanpa dipusingkan dengan urusan-urusan tambahan, dan memperkerjakan karyawan secara parsial dan temporal sesuai dengan kebutuhan penanganan masalah yang diperlukan baik dalam bentuk kerumunan langsung atau disederhanakan dalam bentuk kelompok yang lebih kecil (peer) (Andriansyah, et al., 2009).

Berdasarkan uraian di atas dapat disimpulkan beberapa hal yaitu crowdsourcing merupakan pengalihan pekerjaan dari pekerjaan yang dulu dikerjakan oleh petugas khusus kemudian beralih menjadi pekerjaan dilakukan oleh orang secara umum, kelompok tertentu atau masyarakat tertentu. Crowdsourcing bertujuan untuk menciptakan sebuah produk maupun juga informasi terbaik. Orang-orang yang bergabung dalam crowdsourcing biasanya memiliki passion atau rasa tertarik pada produk yang dihasilkan. Oleh karena itu, crowdsourcing dilaksanakan secara sukarela. Crowdsourcing dapat dilakukan oleh kelompok orang tertentu dengan menerima kompensasi atau 
tanpa kompensasi apapun. Kompensasi bagi pelaku crowdsourcing itu bukan tujuan dari dilakukan pekerjaan.

\section{Metode Penelitian}

Makalah ini menggunakan metode pengumpulan data studi literatur. Menurut Sugiyono (2012), studi literatur berkaitan dengan kajian teoritis dan referensi lain yang berkaitan dengan nilai, budaya dan norma yang berkembang pada situasi sosial yang diteliti, selain itu studi kepustakaan sangat penting dalam melakukan penelitian, hal ini dikarenakan penelitian tidak akan lepas dari literatur-literatur Ilmiah. Studi literatur biasanya digunakan untuk mengumpulkan data-data yang berhubungan dengan topik penelitian. Cara yang dilakukan dengan membaca dan belajar dari buku-buku ilmu pengetahuan, catatan, dokumen tertulis, literatur, jurnal, dan lain sebagainya yang berhubungan dengan topik pembahasan. Dalam peneliti ini menggunakan studi literatur dengan mengumpulkan berbagai informasi mengenai crowdsourcing dan implikasinya dalam perpustakaan.

\section{Sejarah Crowdsourcing}

Crowdsourcing bukan merupakan ide yang benarbenar baru. Jeff Howe telah melemparkan ide tersebut untuk pertama kali pada tahun 2006. Jeff Howe yang memproyeksikan jika ada orang-orang di luar perusahaan mampu memberikan kontribusi besar pada suatu proyek. Jeff Howe melihat bagaimana pola suatu pekerjaan dikirim kepada orang-orang yang berada di Cina atau India. Konsep pengalihan pekerjaan semacam itu adalah untuk mendapatkan tenaga kerja murah dengan hasil yang optimal. Sistem kerja tersebut dinamakan outsourcing.

Selanjutnya Howe memperkenalkan konsep crowdsourcing. Crowdsourcing dapat diartikan sebagai adanya orang-orang di luar perusahaan namun tidak memiliki hubungan sama sekali dengan perusahaan sebelumnya. Melalui crowdsourcing orang-orang tersebut menjadi sumber pendanaan terbesar yang tidak bisa ditinggalkan oleh perusahaan. Tentunya orang-orang tersebut juga turut ambil andil dan memberikan idenya demi pencapaian yang diinginkan.

Crowdsourcing semakin menjamur dikarenakan konsep ini dianggap dapat menekan biaya produksi terutama biaya tenaga kerja. Dengan konsep crowdsourcing, masyarakat dapat berpartisipasi langsung dalam mengembangkan suatu usaha. Salah satu contoh crowdsourcing adalah Gojek. Gojek melibatkan masyarakat secara langsung untuk berperan serta dalam suatu usaha, dimana masyarakat luas diberikan kebebasan untuk ikut serta menjadi salah satu tenaga kerja. Contohnya seperti perusahaan yang memerlukan sebuah desain untuk keperluan pemasaran mereka, perusahaan tidak perlu mempekerjakan seorang grafik desainer yang menambah pengeluaran untuk menggaji karyawan, perusahaan tersebut dapat menggunakan situs crowdsourcing desain (99design.com). Sebagai contoh lain, GOJEK tidak perlu menggaji karyawan yang digunakan sebagai pengemudi gojek, karyawan tersebut menggaji diri sendiri dengan mencari penumpang dengan sistem komisi. Contoh lain adalah kontributor suatu informasi pariwisata suatu daerah. Kontributor bukan bagian perusahaan atau institusi penyedia jasa pariwisata. Kontributor adalah orang di luar perusahaan yang dapat menambahkan informasi sesuai yang diketahuinya.

\section{Kelebihan Crowdsourcing}

Crowdsourcing berbeda dengan outsourcing. Crowdsourcing dirasakan memiliki kelebihan dan juga kekurangan. Kelebihan Crowdsourcing dapat meningkatkan produktivitas tanpa menambah tenaga kerja. Perkembangan teknologi internet menjadikan masyarakat, dan konsumen, dapat terlibat secara langsung dalam suatu proyek tertentu. Misalnya, memberikan komentar positif saat membeli produk atau menggunakan jasa secara online. Dengan demikian, konsumen juga membantu memasarkan sebuah produk. Selain itu, crowdsourcing dapat menekan biaya yang besar dan hasil yang maksimal.

\section{Kekurangan Crowdsourcing}

Namun Crowdsourcing diklaim juga memiliki kelemahan. Diantaranya adalah dalam sisi keamanan. Besarnya partisipasi masyarakat membuat kontrol terhadap segala informasi menjadi tidak terkontrol. Sehingga semakin terbukanya dan cepatnya akses menyebabkan penyebaran konten yang tidak bertanggung jawab. Oleh sebab itu, kita harus secara dewasa menggunakan konsep crowdsourcing dalam sebuah bisnis.

\section{Implimentasi Crowdsourcing dalam Dunia Perpustakaan}

Konsep crowdsourcing dapat diaplikasikan dalam perpustakaan. Mengapa demikian, karena perpustakaan merupakan lembaga nirlaba yang membutuhkan 
keikutsertaan pemustaka baik dalam mengembangkan perpustakaan juga dalam rangka melaksanakan kegiatan di perpustakaan. Pemustaka atau bahkan masyarakat secara luas dapat ikut serta memberikan ide, gagasan atau pendapat dalam rangka mempromosikan perpustakaan. Aktivitas tersebut antara lain adalah:

1. Resensi oleh para pemustaka

Perpustakaan pada umumnya menggelar resensi buku dan dicantumkan secara online di website perpustakaan. Resensi buku ini bertujuan untuk menarik minat pemustaka untuk datang dan membaca buku yang dianggap menarik tersebut. Resensi buku biasanya dilakukan oleh pustakawan. Dalam crowdsourcing, resensi buku bukan lagi domain pustakawan. Pemustaka dapat berperan ikut meresensi buku yang ada di perpustakaan. Resensi yang dilakukan oleh pemustaka ini akan menjadi menarik karena pemustaka ikut serta dalam memberikan ulasan versi pemustaka sehingga akan dipandang lebih objektif. Pustakawan dapat berperan sebagai admin, sehingga berhak menyeleksi tulisan mana yang dapat ditampilkan dalam website perpustakaan. Tentu saja resensi yang diterima tidak melanggar ketentuan yang berlaku.

2. Komen/rekomendasi pemustaka mengenai suatu koleksi yang telah dibaca.

Salah satu cara menarik perhatian pengguna dalam memanfaatkan koleksi perpustakaan adalah komentar atau rekomendasi tentang beberapa judul buku yang telah dibaca atau dipinjam. Rekomendasi ini dapat ditayangkan di website atau alat promosi di sekitar rak buku. Rekomendasi buku yang dibaca ini dapat juga dengan memberi tanda bintang pada saat mengembalikan buku di perpustakaan. Rating bintang dapat ditampilkan di OPAC. Pemustaka yang lain dapat mengetahui rating buku tersebut dan berapa banyak pemustaka yang telah memanfaatkan buku tersebut.

3. Magang di perpustakaan

Magang di perpustakaan merupakan salah satu bentuk crowdsourcing. Pemustaka dapat berpartisipasi dalam pengelolaan perpustakaan. Pada perpustakaan perguruan tinggi, dapat dilaksanakan program magang di perpustakaan. Pengisi magang di perpustakaan adalah setiap mahasiswa yang mau meluangkan waktu untuk mengelola perpustakaan di sela-sela kesibukan kuliah. Bagi perpustakaan, dengan adanya pemustaka magang tidak saja dapat membantu dalam beberapa pekerajaan teknis. Pemustaka magang harus mempresentasikan ide dan gagasan pengembangan perpustakaan. Tentu saja pemustaka magang juga memberikan pendapatnya mengenai kelebihan dan kekurangan perpustakaan.

4. Library volunteer

Library volunteer ini berbeda dengan magang di perpustakaan. Jika pemustaka magang lebih banyak berkecimpung dalam kegiatan teknis perpustakaan. Library volunteer ini biasanya ikut berperan di beberapa program yang dilaksanakan oleh perpustakaan. Library volunteer lebih banyak bergerak untuk kegiatan perpustakaan, misal pameran buku di perpustakaan, hari kunjung perpustakaan, pengenalan perpustakaan, seminar, talk show, sarasehan dan lain sebagainya. Library volunteer ini banyak bergerak untuk kegiatan-kegiatan kreatif perpustakaan. Khususnya mengadakan kegiatankegiatan yang cocok bagi kalangan pemustaka milenial. Keikutsertaan pemustaka dalam merancang program kreatif di perpustakaan ini penting. Di era milenial ini, perpustakaan telah bermetamorfosis mengembangkan program kreatif perpustakaan guna menarik minat pemustaka. Program-program kreatif ini dapat digali dari pemustaka. Mekanisme merancang program kreatif ini dapat dilakukan secara online atau offline. Selain itu dapat dilakukan secara langsung dengan menggelar pertemuan antara pihak pustakawan dan pemustaka.

5. Pemustaka ikut serta membuat subject guide Pustakawan di satu sisi dituntut untuk menjadi subject spesialis dengan memahami peta ilmu dalam satu bidang tertentu. Namun tidak dipungkiri perkembangan ilmu pengetahuan itu begitu luas dan cepat. Pustakawan harus belajar dari pemustaka khususnya dalam mengembangkan subject guide. Pemustaka dapat yang memberikan masukan bagi subject guide ini biasanya dari kalangan akademisi, mahasiswa pada jurusan tersebut atau kelompok dalam masyarakat yang memahami bidang tersebut. Pustakawan akan dapat belajar mengenai peta ilmu kepada pemustaka. Pengembangan subject guide dapat dilakukan melalui FGD/Focus Grup Discussion yang diselenggarakan oleh perpustakaan. Keuntungan dari FGD ini adalah mampu menjaring pengembangan ilmu dan menjaring rekomendasi buku bacaan yang diperlukan oleh pemustaka.

Terkait reward atau hadiah yang diberikan oleh perpustakaan kepada para pemustaka dalam Crowdsourcing, maka perpustakaan dapat menyediakan dana untuk menyediakan hadiah kepada orang-orang yang 
terlibat dalam crowdsourcing. Hadiah yang diberikan dapat berbagai macam. Dapat pula berupa uang atau barang. Fungsi reward adalah untuk memberi semangat kepada pemustaka yang telah ikut berpartisipasi dalam pengembangan perpustakaan. Hadiah atau reward ini bukan suatu kewajiban yang utama karena crowdsourcing dilaksanakan dengan prinsip gotong royong. Orang-orang yang terlibat crowdsourcing dengan suka rela tanpa paksaan. Crowdsourcing ini tidak melulu berkaitan dengan internet.

Manfaat crowdsourcing dapat diimplematasikan di perpustakaan adalah pemustaka dan masyarakat sekitar akan tumbuh rasa ikut memiliki perpustakaan. Dalam melahirkan program-program perpustakaan tidak lagi domain pustakawan. Pustakawan dapat menghimpun ide-ide segar dari para pemustaka. Pustakawan tetap sebagai pihak yang menyeleksi ide-ide mana yang dapat langsung diterapkan, ide mana yang perlu disempurnakan lagi. Pada akhirnya perpustakaan akan tetap diminati bahkan pemustaka sebagai sarana promosi perpustakaan. Pemustaka satu akan mengajak pemustaka yang lain dalam berpartisipasi dalam suatu kegiatan. Ini merupakan suatu promosi yang efisien dan efektif.

\section{KESIMPULAN}

Ada suatu baru yang positif yaitu fenomena gotong royong antar anggota masyarakat untuk satu tujuan tertentu. Setiap orang berhak dan diperbolehkan memberikan informasi yang diperlukan. Fenomena tersebut disebut sebagai crowdsourcing. Crowdsourcing merupakan konsep yang melibatkan masyarakat secara luas dan tidak terbatas dengan latar belakang etnis, warga negara, pendidikan, agama, jenis kelamin ataupun pekerjaan. Sebagaimana jamak diketahui perpustakaan merupakan lembaga nirlaba yang menyediakan jasa layanan informasi kepada pemustaka. Pemustaka atau bahkan masyarakat secara luas dapat ikut serta memberikan ide, gagasan atau pendapat dalam rangka mempromosikan perpustakaan. Aktivitas tersebut antara lain adalah: (1) Resensi oleh para pemustaka; (2) Komen/ rekomendasi pemustaka mengenai suatu koleksi yang telah dibaca; (3) Magang di perpustakaan; (4) Library volunteer; (5) Pemustaka ikut serta membuat subject guide.

\section{DAFTAR PUSTAKA}

Howe, Jeff. 2006. "The Rise of Crowdsourcing”. Wired Issue 14.06 - June 2006

Miftah Andriansyah1, Teddy Oswari2, Budi Prijanto. Crowdsourcing: Konsep Sumber Daya Kerumunan dalam Abad Partisipasi Komunitas Internet.

Sugiyono. 2012. Metode Penelitian Kuantitatif Kualitatif dan R\&D. Bandung: Alfabeta

Wikipedia.com 